\title{
WSS25, a sulfated polysaccharide, inhibits RANKL- induced mouse osteoclast formation by blocking SMAD/ID1 signaling
}

\author{
Cheng CHEN ${ }^{1,2, \#}$, Yi QIN ${ }^{1, ~ \#, ~ J i a n-p i n g ~ F A N G ~}{ }^{1}$, Xin-yan $\mathrm{NI}^{1}$, Jian $\mathrm{YAO}^{1}$, Hai-ying WANG ${ }^{2,4, *}$, Kan DING ${ }^{1, *}$ \\ ${ }^{1}$ Glycochemistry and Glycobiology Laboratory, Shanghai Institute of Materia Medica, Chinese Academy of Sciences, Shanghai 201203, \\ China; ${ }^{2}$ Institute of Traditional Chinese Medicine, Shanghai University of Traditional Chinese Medicine, Shanghai 201203, China
}

\begin{abstract}
Aim: WSS25 is a sulfated polysaccharide extracted from the rhizome of Gastrodia elata BI, which has been found to bind to bone morphogenetic protein 2 (BMP-2) in hepatocellular cancer cells. Since BMP-2 may regulate both osteoclasts and osteoblasts, here we investigated the effects of WSS25 on osteoclastogenesis in vitro and bone loss in ovariectomized mice.

Methods: RAW264.7 cells or mouse bone marrow macrophages (BMMs) were treated with RANKL to induce osteoclastogenesis, which was assessed using TRAP staining, actin ring formation and pit formation assays, as well as bone resorption assay. Cell viability was detected with MTT assay. The mRNA levels of osteoclastogenesis-related genetic markers (TRAP, NFATc1, MMP-9 and cathepsin K) were detected using RT-PCR, while the protein levels of p-Smad1/5/8 and Id1 were measure with Western blotting. WSS25 was administered to ovariectomized mice $\left(100 \mathrm{mg} \cdot \mathrm{kg}^{-1} \cdot \mathrm{d}^{-1}, \mathrm{po}\right)$ for 3 months. After the mice were euthanized, total bone mineral density and cortical bone density were measured.

Results: In RAW264.7 cells and BMMs, WSS25 (2.5, 5, $10 \mu \mathrm{g} / \mathrm{mL})$ did not affect the cell viability, but dose-dependently inhibited RANKL-induced osteoclastogenesis. Furthermore, WSS25 potently suppressed RANKL-induced expression of TRAP, NFATc1, MMP-9 and cathepsin K in RAW264.7 cells. Treatment of RAW264.7 cells with RANKL increased BMP-2 expression, Smad1/5/8 phosphorylation and Id1 expression, which triggered osteoclast differentiation, whereas co-treatment with WSS25 or the endogenous BMP-2 antagonist noggin suppressed the BMP-2/Smad/Id1 signaling pathway. In RAW264.7 cells, knockdown of Id1 attenuated RANKL-induced osteoclast differentiation, which was partially rescued by Id1 overexpression. In conformity to the in vitro experiments, chronic administration of WSS25 significantly reduced the bone loss in ovariectomized mice.

Conclusion: WSS25 inhibits RANKL-induced osteoclast formation in RAW264.7 cells and BMMs by blocking the BMP-2/Smad/Id1 signaling pathway. WSS25 administration reduces bone loss in ovariectomized mice, suggesting that it may be a promising therapeutic agent for osteoporosis.
\end{abstract}

Keywords: WSS25; polysaccharides; osteoclast; RANKL; BMP-2; Smad1/5/8; Id1; ovariectomized mice; osteoporosis

Acta Pharmacologica Sinica (2015) 36: 1053-1064; doi: 10.1038/aps.2015.65; published online 24 Aug 2015

\section{Introduction}

Bone is a dynamic tissue that is continuously destroyed and reformed by a series of highly regulated process, including bone resorption by osteoclasts and bone formation by osteoblasts $^{[1]}$. Osteoporosis is a progressive bone disease characterized by low bone density that results from an imbalance between osteoclast and osteoblast activities ${ }^{[2,3]}$. Two essential factors involved in osteoclast formation are the recep-

\footnotetext{
\#These authors contributed equally to this work.

* To whom correspondence should be addressed.

E-mail dingkan@simm.ac.cn (Kan DING);

wanghaiying_7@hotmail.com (Hai-ying WANG)

Received 2014-12-31 Accepted 2015-05-28
}

tor activator of nuclear factor kappa B ligand (RANKL) and macrophage colony-stimulating factor (M-CSF) ${ }^{[4,5]}$. RANKL specifically regulates the process of osteoclast formation by activating the receptor activator of NF-kB (RANK) or its decoy receptor osteoprotegerin (OPG) on mononuclear precursors of monocytes/macrophages ${ }^{[6]}$. M-CSF plays an important role in survival and proliferation of osteoclast precursors, and disruption of M-CSF in mice prevents osteoclastogenesis and hence induces osteopetrosis ${ }^{[7]}$.

RANKL binds to its physiologic receptor RANK, a member of the tumor necrosis factor receptor (TNFR) superfamily, and activates specific signaling pathways including the NF- $\mathrm{B}$, c-Jun N-terminal kinase (JNK), p38, and extracellular signalregulated kinase $(\mathrm{ERK})$ pathways ${ }^{[8-10]}$. Moreover, it has been 
suggested that nuclear factor of activated T cells (NFATc1) is crucial for osteoclast differentiation and that it is upregulated by RANKL through activation of the NF-KB and JNK/AP-1 signaling pathways ${ }^{[1]}$. In addition, NFATc1 directly regulates the expression of osteoclastogenesis-related marker genes, including tartrate-resistant acid phosphatase (TRAP), matrix metalloproteinase 9 (MMP-9), and cathepsin $\mathrm{K}^{[12]}$.

Bone morphogenetic proteins (BMPs), which compose a subclass of the transforming growth factor- $\beta$ (TGF- $\beta$ ) superfamily, play important roles in skeletal development ${ }^{[13]}$. It has been reported that BMP-2 may regulate both osteoclasts and osteoblasts and that it may directly promote RANKL-induced osteoclast differentiation ${ }^{[14,15]}$. After binding to its type I or II receptors (BMPR-IA, BMPR-IB, and BMPR-II), BMP-2 promotes the phosphorylation of Smad1/5/8 and activates the transcription of target genes. One of these target genes is Id1 (inhibitor of differentiation or DNA binding), which is a negative regulator of cell differentiation and a positive regulator of cell proliferation ${ }^{[16,17]}$. Id1 gene knockout reduced bone mass and increased bone fragility in mice, and loss of Id1 increased osteoclast differentiation and resorption activity in vivo and in vitro ${ }^{[18]}$. In addition, noggin is an endogenous inhibitor of BMPs that can bind to BMP-2 and block the interaction between BMP-2 and its receptors ${ }^{[19]}$. Moreover, noggin dosedependently decreased osteoclast formation in vitro ${ }^{[20]}$. Overexpression of noggin clearly impaired osteoclast formation and reduced osteoclastic bone resorption, while recombinant BMP-2 rescued it, in vivo ${ }^{[13]}$.

Currently, therapeutic drugs for osteoporosis act mainly by suppressing osteoclast resorption and/or increasing osteoblast formation. However, drugs used for these clinical treatments are far from ideal. For example, bisphosphonates accumulate in bone and are released for many months or years after treatment is stopped ${ }^{[21]}$. Bisphosphonates are also poorly absorbed and can induce severe hypocalcemia in patients with hypoparathyroidism and renal damage ${ }^{[22]}$. Another drug, parathyroid hormone $(\mathrm{PTH})$, stimulates bone formation, but this treatment is limited to two years of use due to concerns regarding osteosarcomas $^{[23]}$. In addition, estrogen replacement therapy, which is frequently used by postmenopausal women, has been associated with an increasing risk of coronary heart disease and ovarian cancer when used as a long-term treatment ${ }^{[24]}$. Due to these side effects and the limitations of long-term treatment, new drugs with fewer side effects are urgently needed for the treatment of osteoporosis.

WSS25, a sulfated derivative of an a-1-4-linked glucan with an a-1-4-linked glucan branch attached at O-6, was extracted from the rhizomes of Gastrodia elata $\mathrm{BI}^{[25]}$. A previous study in our lab demonstrated that WSS25 binds to BMP-2 and that its receptors inhibited xenografted hepatocellular cancer cell growth and disrupted angiogenesis ${ }^{[26-28]}$. As we mentioned above, BMP-2 is also a crucial factor in bone remodeling. We therefore explored the function of and precise mechanisms involved in the effect of WSS25 on RANKL-induced osteoclastogenesis in this study.

\section{Materials and methods \\ Reagents}

WSS25 $\left(M_{\mathrm{w}}=8.64 \times 10^{5} \mathrm{~g} / \mathrm{mol}\right.$, polydispersity calculated from $M_{\mathrm{w}} / M_{\mathrm{n}}$ is 2.61) was prepared in this laboratory as previously described $^{[25]}$. Alpha Dulbecco's modified Eagle's medium (a-DMEM) was purchased from Invitrogen (Carlsbad, CA, USA), and fetal bovine serum (FBS) was purchased from GIBCO-BRL (Grand Island, NY, USA). Recombinant murine RANKL was purchased from Peprotech (Rocky Hill, USA). M-CSF and noggin were purchased from R\&D Systems (Minneapolis, MN, USA). Recombinant bone morphogenetic protein-2 (BMP-2) was obtained from Shanghai PrimeGene BioTech Co, Ltd (Shanghai, China). Antibodies for p-Smad1/5/8 and $\beta$-actin were purchased from Cell Signaling Technology (USA). Antibodies for Id1, BMPR IA, BMPR IB, and BMPR II were obtained from Santa Cruz Biotechnology (Santa Cruz, CA, USA). TRIzol reagent was purchased from Invitrogen (Carlsbad, CA, USA). MTT and tartrate-resistant acid phosphatase (TRAP) staining kits were purchased from Sigma (St Louis, MO, USA). Alkaline phosphatase kits were purchased from Beyotime Biotechnology (Shanghai). The Moloney murine leukemia virus (M-MLV) reverse transcriptase and reverse transcription PCR reagent kits were purchased from Takara Biotechnology (Dalian, China). Strontium ranelate and 17 beta-estradiol were purchased from Melone Pharmaceuticals (Dalian, China). Raw264.7 cells were purchased from the Cell Resource Center of the Shanghai Institutes for Biological Sciences.

\section{Cell culture and tartrate-resistant acid phosphatase (TRAP) staining}

Bone marrow cells were prepared by removing femurs from 6-week-old female ICR mice and flushing the bone marrow cavity with a-DMEM containing $10 \%$ FBS, as previously described $^{[29]}$. Bone marrow cells were cultured overnight with M-CSF ( $5 \mathrm{ng} / \mathrm{mL}$ ). On the following day, non-adherent cells were further cultured with M-CSF $(20 \mathrm{ng} / \mathrm{mL})$ for $3 \mathrm{~d}$. Adherent cells were used as bone marrow derived monocytes (BMMs). BMMs and RAW264.7 cells were cultured with a-DMEM containing 10\% FBS in a humidified incubator at $37^{\circ} \mathrm{C}$ with $5 \% \mathrm{CO}_{2}$. For TRAP staining, BMMs $\left(5 \times 10^{4}\right.$ cells/ well) were cultured with M-CSF $(20 \mathrm{ng} / \mathrm{mL})$ and RANKL (50 $\mathrm{ng} / \mathrm{mL}$ ) in the presence or absence of different concentrations of WSS25 $(2.5,5$, or $10 \mu \mathrm{g} / \mathrm{mL})$. After $7 \mathrm{~d}$, the cells were fixed and stained using a TRAP kit according to the manufacturer's protocol. TRAP-positive multinucleated cells with more than two nuclei were counted as osteoclasts. RAW264.7 cells $\left(1 \times 10^{5}\right.$ cells/well) were stimulated with RANKL ( $50 \mathrm{ng} / \mathrm{mL}$ ) and treated with different concentrations of WSS25. Four days later, the cells were fixed and stained with a TRAP kit and osteoclasts were counted under light microscopy.

\section{Cytotoxicity test}

The MTT method was employed to study the cytotoxicity of WSS25. BMMs and RAW264.7 cells were treated with various 
concentrations of WSS25 in 96-well plates $\left(2.0 \times 10^{5}\right.$ cells $/ \mathrm{mL}$, $0.1 \mathrm{~mL} /$ well) for three days. MTT solution (3-[4,5-dimethylthiazol-2-yl]-2,5-diphenylterazolium bromide, $5 \mathrm{mg} / \mathrm{mL} ; 10 \mu \mathrm{L} /$ well) was added to the wells and the plates were incubated at $37^{\circ} \mathrm{C}$ for $4 \mathrm{~h}$, followed by the removal of the medium and the addition of $200 \mu \mathrm{L} /$ well DMSO. After shaking at room temperature for several minutes, the absorbance of each well was measured at $490 \mathrm{~nm}$ using a spectrophotometer (Thermo Multiskan MK3, Germany).

\section{Actin ring formation and pit formation assay}

RAW264.7 cells were cultured with RANKL $(50 \mathrm{ng} / \mathrm{mL})$ and varying concentrations of WSS25. After $4 \mathrm{~d}$, cells were fixed with $4 \%$ paraformaldehyde for $20 \mathrm{~min}$ and washed with phosphate buffered saline (PBS) four times. Then, the cells were cultured with fluorescein isothiocyanate (FITC)-phalloidin (5 $\mu \mathrm{g} / \mathrm{mL}$ ) for $30 \mathrm{~min}$ and washed with PBS three times. Cells were then stained for $1 \mathrm{~h}$ with 4',6-diamidino-2-phenylindole (DAPI) $(1 \mu \mathrm{g} / \mathrm{mL})$ and imaged under fluorescence microscopy.

\section{Bone resorption assay}

RAW264.7 cells $\left(1 \times 10^{5}\right.$ cells $\left./ \mathrm{mL}\right)$ were cultured on bovine bone that was sliced as has been previously described ${ }^{[30]}$. Cells were then stimulated by RANKL $(50 \mathrm{ng} / \mathrm{mL})$, with or without WSS25 $(10 \mu \mathrm{g} / \mathrm{mL})$, for $5 \mathrm{~d}$. BMMs $\left(5 \times 10^{4}\right.$ cells $\left./ \mathrm{mL}\right)$ were cultured with M-CSF $(20 \mathrm{ng} / \mathrm{mL})$ and RANKL $(50 \mathrm{ng} / \mathrm{mL})$, in the presence or absence of WSS25 $(10 \mu \mathrm{g} / \mathrm{mL})$, on bone slices for $7 \mathrm{~d}$. Bone slices were stained with hematoxylin after cells were completely removed. Resorption pits that formed were photographed in three individual visual fields using a microscope $(\times 1000)$. The resorption areas were analyzed using Image-Pro Plus 6.0 software.

\section{Ovariectomized mouse model and bone mineral density analysis}

Ovariectomized ICR albino mice were used as an animal model, as previously described ${ }^{[31]}$. All animal experiments were performed according to the Guidelines for the Institutional Animal Care and Use Committee in Shanghai Institute of Materia Medica, Chinese Academy of Sciences. First, 7 days after ovariectomy, mice were randomly divided into four groups of 6 mice each. The groups were ovariectomized mice (OVX), and ovariectomized mice treated with WSS25 (100 mg/ kg body weight), strontium ranelate (SR) (500 $\mathrm{mg} / \mathrm{kg}$ body weight), or 17 beta-estradiol $(25 \mu \mathrm{g} / \mathrm{kg}$ body weight). Sham operations on another 6 mice included the removal of a piece of adipose tissue near the ovary. Every group was fed between 15:00-16:00, every day, by forced oral administration. The body weight of each mouse was measured every 10 days. After 3 months, mice were euthanized and the tibia was removed from the left leg, followed by removal of excess muscle, adipose and other tissues. We measured total bone mineral density (BMD) and cortical bone density $(\mathrm{CBD})$ in the proximal tibia $2.0 \mathrm{~mm}$ below the place using peripheral Quantitative Computed Tomography (pQCT) (Stratec, Germany) according to the manufacturer's protocol.

\section{RT-PCR analysis}

Reverse transcription PCR was used to analyze the expression of genetic markers of osteoclastogenesis, including, TRAP, NFATc1, MMP-9, and cathepsin K, in RAW264.7 cells. Cells were treated with RANKL $(50 \mathrm{ng} / \mathrm{mL})$, with or without WSS25 $(2.5,5$ and $10 \mu \mathrm{g} / \mathrm{mL})$, for $4 \mathrm{~d}$, or stimulated with BMP-2 $(100 \mathrm{ng} / \mathrm{mL})$ with or without WSS25 (10 $\mu \mathrm{g} / \mathrm{mL}$ ), for $1,2,3$, or $4 \mathrm{~d}$. Then, total RNA was extracted from cells with TRIzol reagent according to the manufacturer's manual. cDNA was synthesized from $1 \mu \mathrm{g}$ total RNA. TRAP, MMP-9, NFATc1, cathepsin K and $18 \mathrm{~S}$ were amplified using two oligonucleotide primers with a $\mathrm{T}_{\mathrm{m}}$ of 51.0, 53.2, 56.0, 51.0 and $56.0^{\circ} \mathrm{C}$, respectively, for 32 cycles. The following primers were used: mouse TRAP forward, $5^{\prime}$-AGACCCAATGCCACCC-3', and reverse, 5'-GGACCTCCAAGTTCTTATC-3'; mouse MMP-9 forward, 5' ${ }^{\prime}$ TCCAGTTTGGTGTCGC-3', and reverse, 5'-GTCCACTCGGGTAGGG-3'; mouse NFATc1 forward, 5' ${ }^{\prime}$-TGGGAGATGGAAGCAAAGAC-3', and reverse, 5'-ATAGAAACTGACTTGGACGGG-3'; mouse cathepsin K forward, 5' -ATGTGGGTGTTCAAGTTTC-3', and reverse, $5^{\prime}$-TCAATGCCTCCGTTCT- $3^{\prime}$; mouse $18 \mathrm{~S}$ forward, 5'-TCCTTTGGTCGCTCGCTCCT-3', and reverse, 5'-TGCTACCTGGCAGGATCAACCAGGT-3'.

\section{Western blot analysis}

RAW264.7 cells were treated with different conditions. Cells were then lysed with an equal volume of RIPA solution and protein concentration was determined using a BCA kit. The same amount of protein from each sample was separated by SDS-PAGE and transferred to nitrocellulose (NC) membranes. To block nonspecific binding, the membranes were incubated with $5 \%$ nonfat dry milk in Tris-buffered saline containing $0.1 \%$ Tween-20 (TBST) for $90 \mathrm{~min}$ at room temperature. Then, the membranes were probed with antibodies for $16 \mathrm{~h}$ at $4^{\circ} \mathrm{C}$ with gentle rotation. After washing with TBST four times, the membranes were incubated with a horseradish peroxidase (HRP)-conjugated secondary antibody at $4^{\circ} \mathrm{C}$ overnight. The membranes were visualized by enhanced chemiluminescence (ECL) using Kodak X-OMAT BT film (Xiamen, China).

\section{shRNA interference and overexpression of Id1}

The lentiviral plasmids encoding full-length Id1, a small hairpin RNA (shRNA) that silenced Id1, and a negative control were obtained from the Shanghai GenePharma Company (Shanghai, China). The shRNA vector was co-transfected into 293T cells with the packaging plasmids psPAX and pMD2.G at a ratio of 2:2:1 according to the manufacturer's instructions. The viral supernatant was collected at $48 \mathrm{~h}$ and $72 \mathrm{~h}$. The viral supernatant was concentrated at $80000 \times g$ using a HITACHI (CP100MX) centrifuge. Virosomes were resuspended in new medium and stored at $-80^{\circ} \mathrm{C}$. RAW 264.7 cells $\left(2.0 \times 10^{5}\right.$ cells/ well) were seeded into 12 -well plates and incubated for 16 $\mathrm{h}$, followed by the addition of the viral solution and incubation for $10 \mathrm{~h}$. The viral solution was then replaced with new medium that contained puromycin $(5 \mu \mathrm{g} / \mathrm{mL}$, Sigma) to 
choose positive cells.

\section{Statistics}

Values are described as the mean $\pm S D$. All data were calculated using GraphPad Prism 5.01 software (GraphPad Software, San Diego, CA, USA). Intergroup differences were analyzed by Student's $t$-test. $P<0.05$ was considered a statistically significant difference.

\section{Results}

WSS25 inhibits osteoclastogenesis in mouse bone marrow monocytes (BMMs) and RAW264.7-derived macrophages

We used two osteoclastogenesis models to study the effect of WSS25 on osteoclast formation in vitro, including mouse bone marrow monocytes (BMMs) and RAW264.7 cells. Tartrateresistant acid phosphate (TRAP) is a glycosylated monomeric metalloprotein enzyme that is a highly expressed, well-known
A

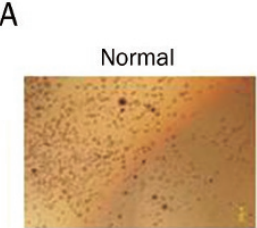

B

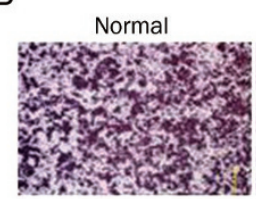

C

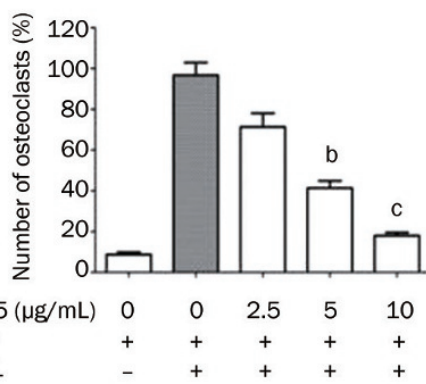

E
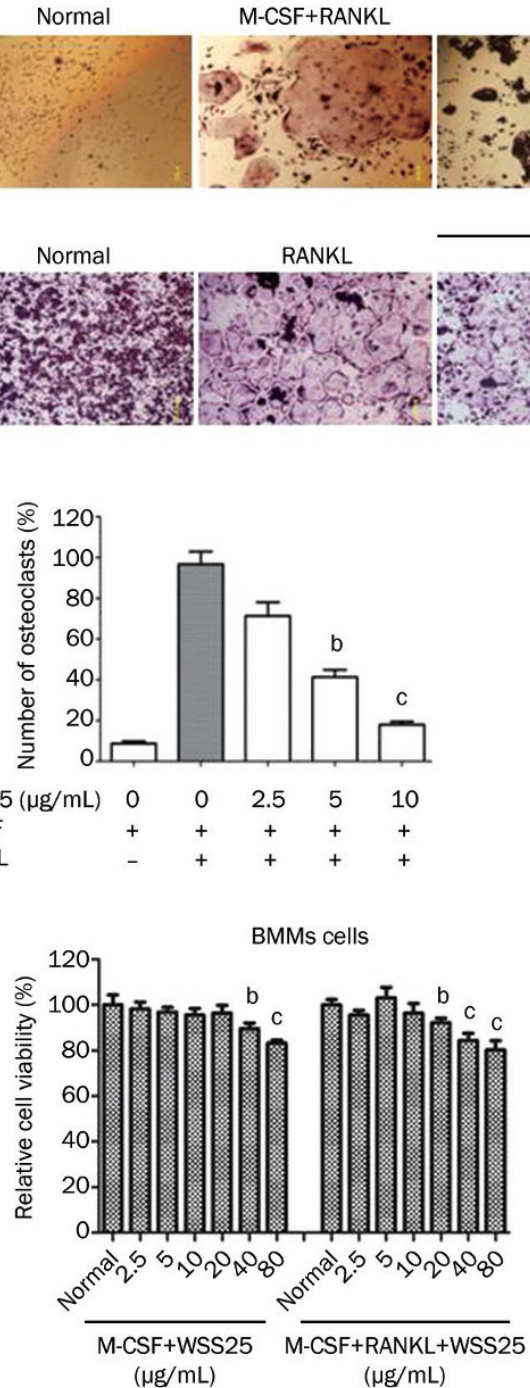

M-CSF+RANKL+WSS25 $(\mu \mathrm{g} / \mathrm{mL})$

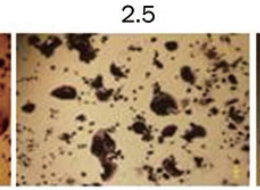

10

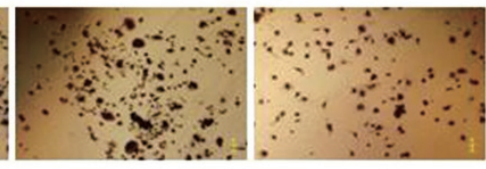

RANKL+WSS25 $(\mu \mathrm{g} / \mathrm{mL})$

2.5

5

10

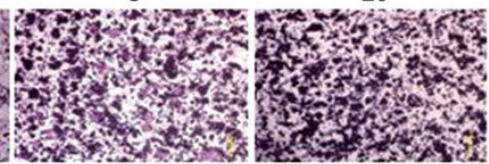

D

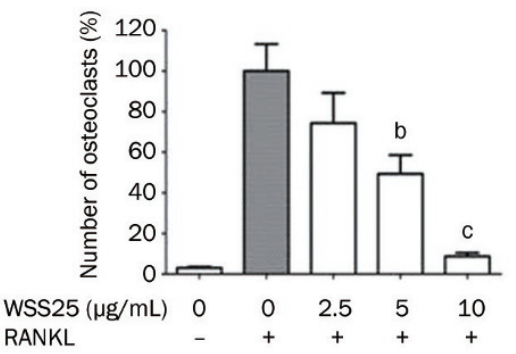

$\mathrm{F}$

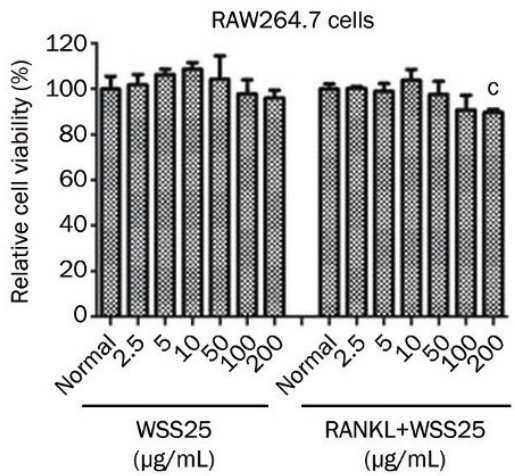

Figure 1. WSS25 inhibits RANKL-induced osteoclast differentiation in mouse bone marrow monocytes (BMMs) and RAW264.7 cells. (A) Mouse BMMs $\left(5 \times 10^{4}\right.$ cells $\left./ \mathrm{mL}\right)$ were treated with M-CSF $(20 \mathrm{ng} / \mathrm{mL})$ and RANKL $(50 \mathrm{ng} / \mathrm{mL})$ in the presence or absence of WSS25 $(2.5,5 \mathrm{and} 10 \mu \mathrm{g} / \mathrm{mL})$. After $7 \mathrm{~d}$ of treatment, the cells were stained with a TRAP kit and photographed $(\times 1000)$. (B) RAW264.7 cells $\left(1 \times 10^{5}\right.$ cells $\left./ \mathrm{mL}\right)$ were incubated with RANKL $(50 \mathrm{ng} / \mathrm{mL})$ in the presence or absence of WSS25 $(2.5,5$ and $10 \mu \mathrm{g} / \mathrm{mL})$ for $4 \mathrm{~d}$, followed by TRAP-staining. Then, the cells were photographed $(\times 1000)$. (C) The numbers of TRAP-positive, multinucleated ( $\geq 3$ nuclei) osteoclasts were counted in BMMs. $n=3$. Values are shown as the mean \pm SD. ${ }^{\mathrm{b}} P<0.05,{ }^{\mathrm{c}} P<0.01 \mathrm{vs} 0 \mathrm{\mu g} / \mathrm{mL}$ WSS25+RANKL+M-CSF group. (D) The numbers of TRAP-positive, multinucleated ( $\geq 3$ nuclei) osteoclasts were counted

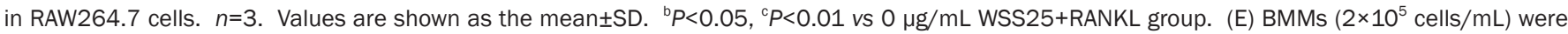
incubated with M-CSF $(20 \mathrm{ng} / \mathrm{mL})$ and the indicated concentration of WSS25 or with M-CSF $(20 \mathrm{ng} / \mathrm{mL})$ plus RANKL (50 ng/mL), in the presence or absence of different concentrations of WSS2 25 for $7 \mathrm{~d}$ before cytotoxicity was tested by MTT assay. (F) RAW264.7 cells $\left(2 \times 10^{5}\right.$ cells $\left./ \mathrm{mL}\right)$ were treated with various concentrations of WSS25 or with WSS 25 plus RANKL $(50 \mathrm{ng} / \mathrm{mL})$ for 7 d before cytotoxicity was tested by MTT assay. $n=3$. Values are shown as the mean \pm SD. ${ }^{b} P<0.05,{ }^{c} P<0.01$ vs normal group. 
marker of osteoclasts. TRAP staining revealed that TRAPpositive, multinucleated osteoclasts were induced by RANKL and M-CSF to form in BMMs within $7 \mathrm{~d}$, and induced by RANKL to form in RAW264.7 cells within $4 \mathrm{~d}$ (Figure 1A and 1B). However, WSS25 significantly inhibited osteoclast differentiation in a dose-dependent manner in both BMMs and RAW264.7 cells (Figure 1A, 1B, 1C and 1D). Moreover, WSS25 had no obvious cytotoxic effects on BMMs or RAW264.7 cells at the concentration used to test the inhibitory effect of WSS25 on osteoclastogenesis (Figure 1E and 1F).

WSS25 suppresses RANKL-induced actin ring formation and the expression of osteoclastogenesis-related markers

Actin ring formation is a prerequisite for the resorption of osteoclasts and is the most distinct marker of mature osteoclasts during osteoclast differentiation ${ }^{[32]}$. To further investigate the effect of WSS25 on osteoclast differentiation, we examined whether WSS25 blocks RANKL-induced actin ring formation in osteoclasts. After stimulation by RANKL, RAW264.7 cells differentiated into mature osteoclasts and formed obvious actin ring structures (Figure 2A). However, the number and size of actin rings gradually decreased as
WSS25 concentrations increased (2.5, 5 and $10 \mu \mathrm{g} / \mathrm{mL}$ ) (Figure 2B and 2C). This indicated that WSS25 inhibited the formation of actin rings in a dose-dependent manner.

RANKL is required to induce the expression of nuclear factor of activated T cells (NFATc1) and osteoclastogenesis related markers, including TRAP, cathepsin K, and MMP$9^{[3]}$. Cathepsin K and MMP-9 are secretory matrix-degrading enzymes that participate in the process of bone resorption ${ }^{[3]}$. To investigate the influence of WSS25 on the expression of RANKL-induced genes, RAW264.7 cells were treated with different concentrations of WSS25 for $4 \mathrm{~d}$ before the mRNA expression levels of NFATc1, cathepsin K, MMP-9 and TRAP were analyzed by reverse transcription PCR. The RANKLinduced expression levels of NFATc1, cathepsin K, MMP-9 and TRAP were significantly inhibited by WSS25 (Figure 2D and $2 \mathrm{E})$.

\section{WSS25 suppresses osteoclastogenesis in the early stage}

Mature osteoclasts are large and multinucleated cells that develop through a series of processes, including proliferation, differentiation and mature osteoclast formation ${ }^{[33]}$. To identify at which stage WSS25 suppressed osteoclast forma-
A
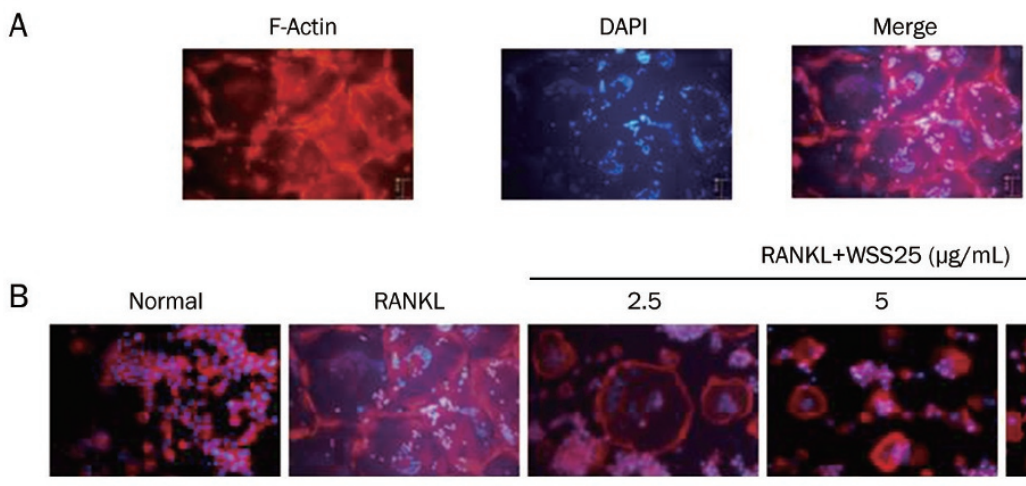

RANKL+WSS25 $(\mu \mathrm{g} / \mathrm{mL})$
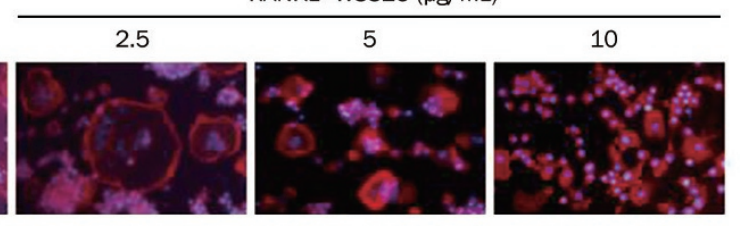

D

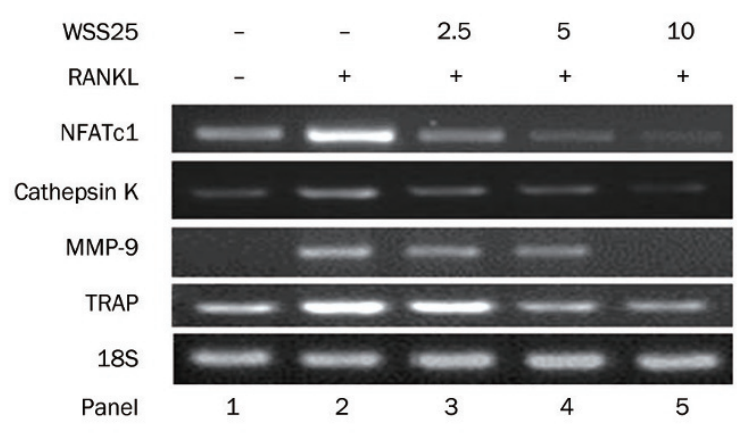

$\mathrm{E}$

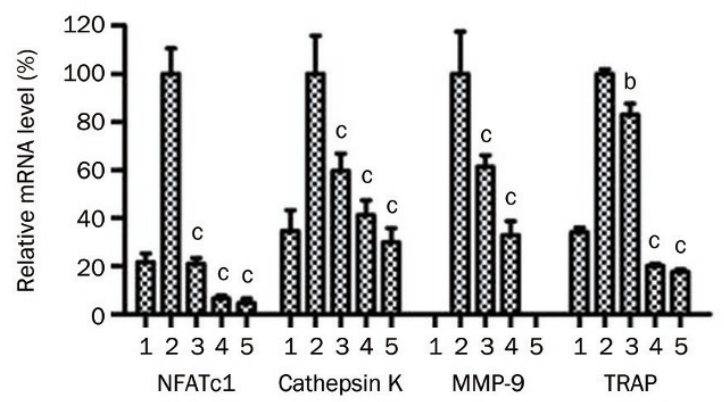

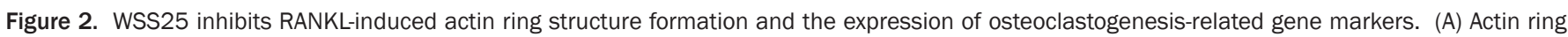

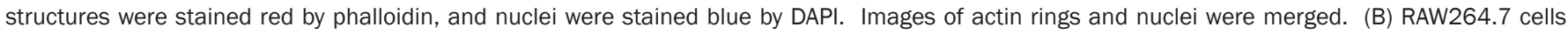

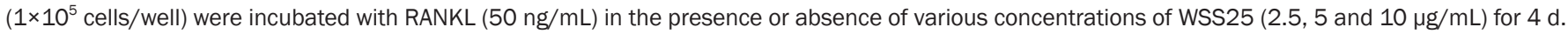

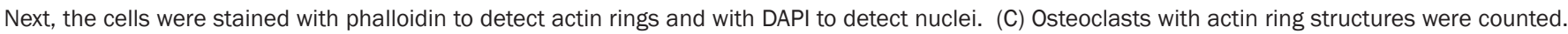

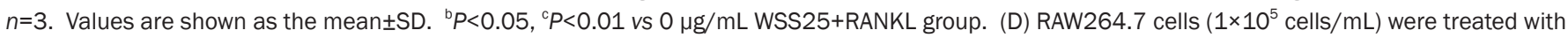

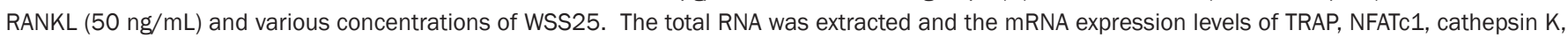

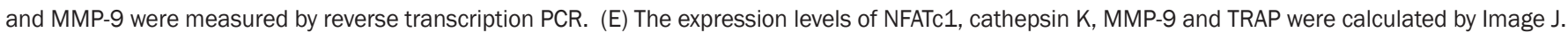
$1-5$ on the $x$-axis refers to panel $1-5$ in (D). $n=3$. Values are shown as the mean $\pm S D$. ${ }^{b} P<0.05,{ }^{c} P<0.01$ vs $0 \mu g / m L$ WSS25+RANKL group. 
A

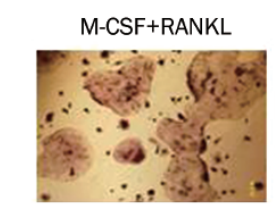

B

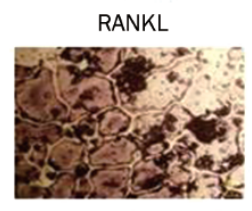

C

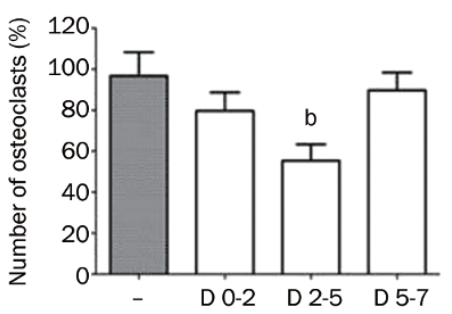

M-CSF+RANKL+WSS25

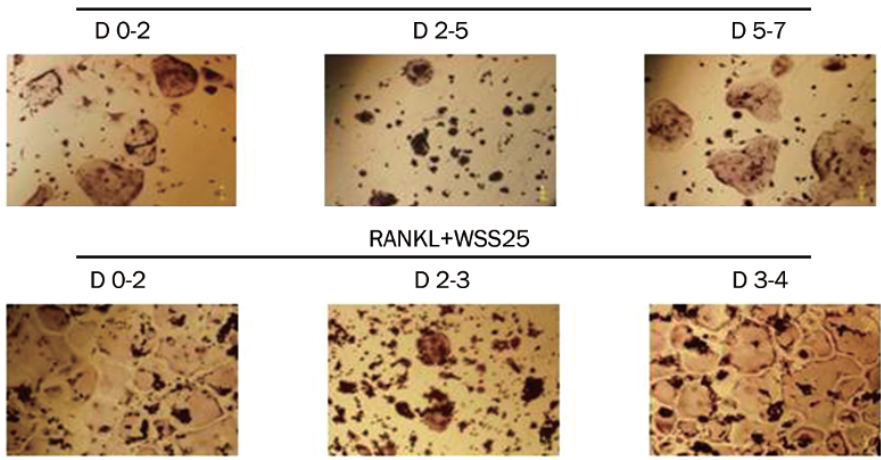

D

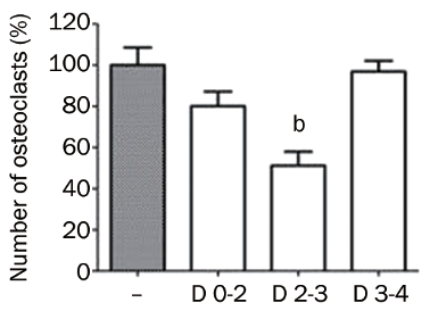

Figure 3. WSS25 inhibits osteogenesis at an early stage. (A) BMMs $\left(5 \times 10^{4}\right.$ cells $\left./ \mathrm{mL}\right)$ were incubated with RANKL $(50 \mathrm{ng} / \mathrm{mL}) \mathrm{plus} \mathrm{M-CSF}(20 \mathrm{ng} / \mathrm{mL})$ and then treated with WSS25 $(10 \mathrm{\mu g} / \mathrm{mL})$ on the indicated days. TRAP-positive, multinucleated osteoclasts were stained after $7 \mathrm{~d}$ of RANKL stimulation, when a photograph was taken $(\times 1000)$. (B) RAW264.7 cells $\left(1 \times 10^{5}\right.$ cells/well) were stimulated with RANKL $(50 \mathrm{ng} / \mathrm{mL})$ and then treated with WSS25 $(10 \mathrm{\mu g} / \mathrm{mL})$ on the indicated days. On the 4th day after WSS25 treatment, TRAP-staining was performed and a photograph was taken $(\times 1000)$. (C) Cells with at least 3 nuclei were counted as multinucleated osteoclasts in BMMs. (D) Cells with at least 3 nuclei were also counted as multinucleated osteoclasts in RAW264.7 cells. $n=3$. Values are shown as the mean \pm SD. ${ }^{b} P<0.05$ vs untreated group.

tion, its inhibitory effect on osteoclastogenesis in BMMs and RAW264.7 cells were investigated by adding WSS25 at different time points after RANKL/M-CSF induction. In BMMs, the number and size of TRAP-positive osteoclasts clearly decreased when WSS25 treatment was administered between days 2-5, but there was no such effect when WSS25 treatment followed induction by more than $5 \mathrm{~d}$ (Figure 3A and 3C). Similarly, WSS25 significantly blocked osteoclast formation in RAW264.7 cells when treatment occurred between days 2-3, whereas there was no such effect by WSS25 treatment when it followed induction by more than 3 days (Figure 3B and 3D). These results suggest that WSS25 inhibits RANKL-induced osteoclast formation during an early stage of osteoclastogenesis.

\section{WSS25 inhibits osteoclastic bone resorption}

To further investigate whether WSS25 suppresses the bone resorption function of osteoclasts, bone resorption assays were performed on RAW264.7 cells and BMMs. RAW264.7 cells were cultured on a bovine bone slice and induced by RANKL, with or without WSS25, for $5 \mathrm{~d}$. Mature osteoclasts resorbed the bone and consequently formed resorbing pits on the slices after RANKL induction (Figure 4A). However, the number of pits and the resorption area on the surface were decreased after WSS25 treatment (Figure 4A, 4B and 4C). Moreover, when BMMs were cultured on a bone slice stimulated by
M-CSF and RANKL, in the presence or absence of WSS25, for $7 \mathrm{~d}$, the number of pits and the resorption area on the surface of the bone slices were also notably decreased (Figure 4D, 4E and $4 \mathrm{~F})$.

\section{WSS25 reduces ovariectomy (OVX)-induced bone loss}

It has been suggested that the main reason for postmenopausal osteoporosis is bone loss caused by estrogen deficiency, which is accompanied by the production of osteoclastogenesis-related cytokines ${ }^{[34,35]}$. To explore whether WSS25 reduces OVX-induced bone loss, an OVX mouse model was employed to mimic postmenopausal bone loss in women ${ }^{[36]}$. Strontium ranelate (SR) decreased osteoclast bone resorption, increased bone formation, and prevented the bone loss normally induced by estrogen deficiency in the OVX mode ${ }^{[37]}$. $17 \beta$-Estradiol also prevented OVX-induced bone loss in mice ${ }^{[38]}$. Therefore, SR and $17 \beta$-estradiol were used as positive controls. As shown in Figure 5A and 5B, OVX mice showed a significant decline in total bone mineral density (BMD) and cortical bone density (CBD) when analyzed using pQCT measurements. However, WSS25 markedly increased BMD and CBD in OVX mice, and SR and 17ß-estradiol prevented OVX-induced bone loss (Figure 5A, 5B). Compared with the sham-operated group, WSS25 had no obvious effect on body weight over 90 days at the concentration tested (Figure 5C). These data suggest that WSS25 reduces ovariectomy-induced bone loss in vivo. 
A
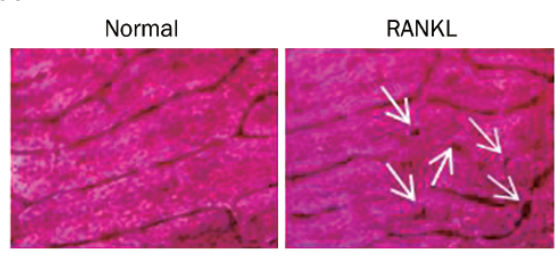

D

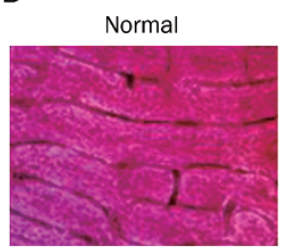

M-CSF+RANKL

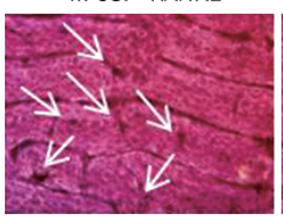

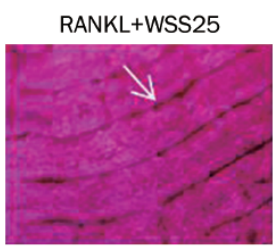

B

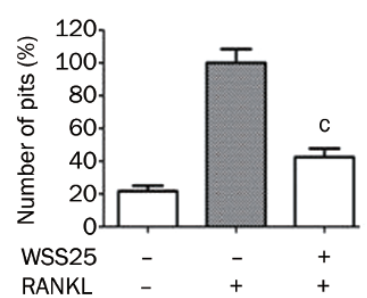

E

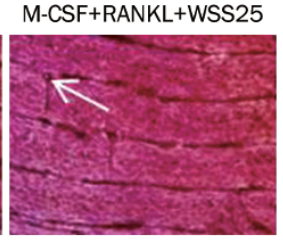

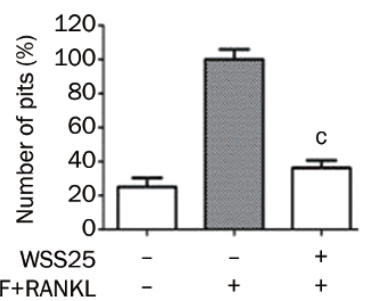

C

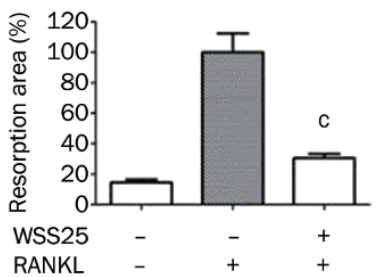

$\mathrm{F}$

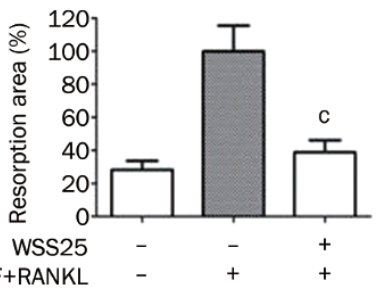

Figure 4. WSS25 inhibits osteoclastic bone resorption in both RAW264.7 cells and BMMs. (A) RAW264.7 cells $\left(1 \times 10^{5}\right.$ cells $\left./ \mathrm{mL}\right)$ were cultured on bone slices and stimulated by RANKL (50 ng/mL), with or without WSS25 (10 $\mu \mathrm{g} / \mathrm{mL})$ for $5 \mathrm{~d}$. Bone slices were stained with hematoxylin after cells were removed. Formed resorption pits were photographed using a microscope $(\times 1000)$. (B) The numbers of resorption pits were counted and statistically analyzed. (C) The areas of resorption pits were calculated using Image-Pro Plus 6.0. $n=3$. Values are shown as the mean \pm SD. ${ }^{c} P<0.01$ vs RANKL group. (D) BMMs $\left(5 \times 10^{4}\right.$ cells $\left./ \mathrm{mL}\right)$ were cultured with M-CSF $(20 \mathrm{ng} / \mathrm{mL})$ and RANKL $(50 \mathrm{ng} / \mathrm{mL})$, in the presence or absence of WSS25 $(10 \mu \mathrm{g} / \mathrm{mL})$, on bone slices for $7 \mathrm{~d}$. Bone slices were then stained with hematoxylin and photographed $(\times 1000)$. (E) The numbers of resorption pits were counted and statistically analyzed. (F) The areas of resorption pits were calculated by Image-Pro Plus 6.0. $n=3$. Values are shown as the mean \pm SD. ${ }^{c} P<0.01$ vs M-CSF+RANKL group.

\section{WSS25 blocks the RANKL-induced phosphorylation of Smad1/5/8 in RAW264.7 cells}

As we have previously reported, WSS25 binds to BMP-2 to block downstream Smad1/5/8 and Id1 signaling pathways ${ }^{[26]}$. To explore the mechanisms contributing to the inhibitory effect of WSS25 on osteoclast formation, RAW264.7 cells were stimulated with RANKL and treated with WSS25 for $22 \mathrm{~h}$, followed by measurements of the phosphorylation of Smad1/5/8 by Western blot analysis. The phosphorylation of Smad1/5/8 was significantly promoted by RANKL. However, $10 \mu \mathrm{g} / \mathrm{mL}$ of WSS25 efficiently blocked RANKL-induced phosphorylation of Smad1/5/8 (Figure 6A). Noggin, a BMP-2 endogenous antagonist, had an inhibitory effect similar to that of WSS25 (Figure 6B). As the direct intracellular effectors of BMP-2, phosphorylated Smad1/5/8 was also promoted by exogenous BMP-2 in RAW264.7 cells (Figure 6C). However, WSS25 or noggin blocked the BMP-2 induced phosphorylation of Smad1/5/8 (Figure 6D).

It has been suggested that BMP-2 promotes bone formation by osteoblasts. However, other studies have shown that BMP-2 induces osteoclast differentiation ${ }^{[15,39,40]}$. To understand the mechanisms underlying the mediation of RANKLinduced osteoclast differentiation by WSS25, we investigated the RANKL-induced protein expression level of BMP-2 in RAW264.7 cells. RAW264.7 cells were stimulated with RANKL and treated with WSS25 from 0 to $4 \mathrm{~d}$, followed by analysis of BMP-2 expression by immunoblotting (Figure $6 \mathrm{E})$. The results indicated that BMP-2 expression was gradually increased by RANKL and that WSS25 blocked RANKLinduced increases in BMP-2 expression.
Osteoclast formation induced by RANKL can be enhanced by BMP-2 and blocked by WSS25 in RAW264.7 cells

To study the influence of BMP-2 on osteoclast differentiation, RAW264.7 cells were incubated with BMP-2, RANKL, or both in the presence or absence of WSS25 or noggin for $4 \mathrm{~d}$. TRAPpositive, multinucleated, osteoclast-like cells were stained. RAW264.7 cells did not differentiate into multinucleated osteoclasts following stimulation by BMP-2 alone (Figure 7A). However, when cells were treated with suboptimal RANKL (20 ng/mL), administered at less than half of the effective dose, a modest number of relatively small, multinucleated osteoclasts were observed. The addition of BMP-2 markedly enhanced the number and average diameter of TRAP-positive osteoclasts that were induced by suboptimal RANKL (Figure 7A, 7B and 7C). The addition of WSS25 or the BMP-2-antagonist noggin significantly inhibited the osteoclast formation that was induced by BMP-2 and suboptimal RANKL (Figure 7A, 7B and 7C). To investigate whether endogenous BMP-2 signaling is a prerequisite for the differentiation of osteoclast precursor cells, RAW264.7 cells were incubated with RANKL (50 ng/mL) and treated with the endogenous BMP-2 antagonist noggin or WSS25. As shown in Figure 7D, noggin and WSS25 sharply blocked osteoclast formation, indicating that the endogenous BMP-2 signaling pathway also participates into osteoclastogenesis.

WSS25 blocks the RANKL or BMP-2 induced expression of Id1 in RAW264. 7 cells

WSS25 downregulated the phosphorylation of Smad1/5/8, and Id1 is a downstream effector of the BMP2/Smad1/5/8 
A

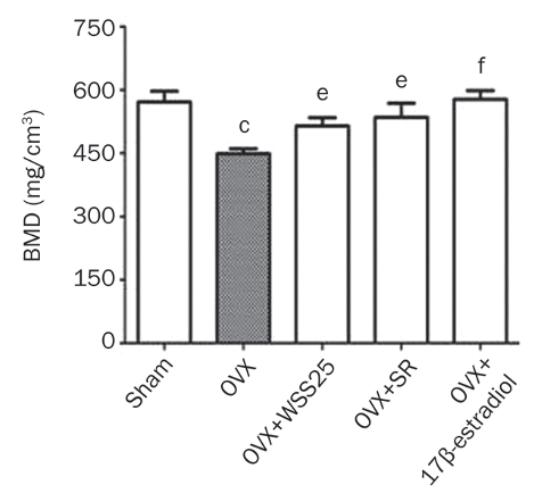

B

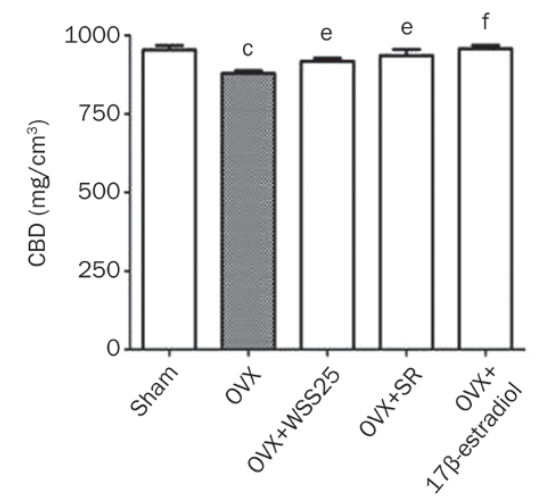

C

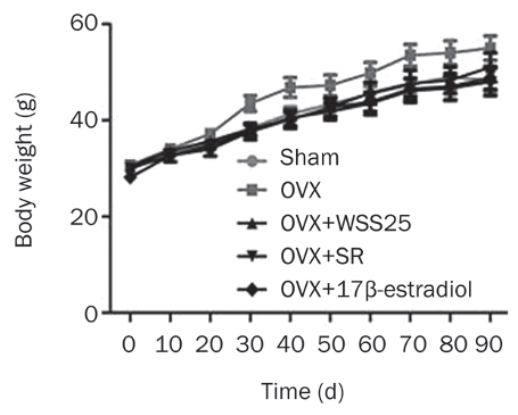

Figure 5. WSS25 reduces ovariectomy-induced bone loss in vivo. (A) Total bone mineral densities (BMD) of tibias from sham-operated mice, OVX mice, and mice treated with WSS25, strontium ranelate, or $17 \beta$-estradiol for $90 \mathrm{~d}$ were measured. (B) Cortical bone densities of tibias were also measured according to the above described method. (C) Each group of mice was orally administered $0.9 \%$ physiological saline, $100 \mathrm{mg} / \mathrm{kg}$ of WSS $25,500 \mathrm{mg} / \mathrm{kg}$ of SR or $25 \mu \mathrm{g} / \mathrm{kg}$ of $17 \beta$-estradiol every day for 90 d. Body weights were recorded every $10 \mathrm{~d}$. $n=6$. Values are shown as the mean \pm SD. ${ }^{\mathrm{c}} P<0.01$ vs sham group. ${ }^{\mathrm{e}} P<0.05,{ }^{\mathrm{f}} P<0.01$ vs $\mathrm{OVX}$ group.

signaling pathway. To investigate the influence of WSS25 on Id1, RAW264.7 cells were cultured with RANKL and treated with WSS25 for $22 \mathrm{~h}$, followed by measurement of Id1 expression by Western blot analysis. Indeed, RANKL promoted the expression of Id1, while WSS25 blocked RANKL-induced expression of Id1 (Figure 8A). When cells were treated with noggin for $22 \mathrm{~h}$, the expression of Id1 was also inhibited. This inhibitory effect was similar to that of WSS25 (Figure 8B). In addition, the expression of Id1 was gradually increased by BMP-2 from 0 to 60 min of treatment in RAW264.7 cells (Figure $8 \mathrm{C}$ ). However, after treatment with WSS25 or noggin for $60 \mathrm{~min}$, BMP2-induced Id1 expression was significantly suppressed (Figure 8D).

To examine whether Id1 plays a role in RANKL mediated osteoclast differentiation, Id1 was knocked down in RAW264.7 cells down by retroviral infection with Id1-shRNA. The expression of Id1 was markedly decreased after infection, as shown by analysis using reverse transcription PCR and Western blot analysis (Figure 8E). Cells were then treated with RANKL for $4 \mathrm{~d}$, followed by staining to measure TRAP expression. The formation of RANKL-induced osteoclasts was significantly decreased when Id1 expression was disrupted in RAW264.7 cells (Figure 8E). To confirm the role of Id1 in RANKL-induced osteoclastogenesis, Id1 knockdown cells were infected with an Id1-overexpressing retrovirus (Figure 8F). Id1 overexpressed cells were treated with RANKL for $4 \mathrm{~d}$, followed by TRAP staining. The results indicated that overexpressed Id1 partly rescued the formation of osteoclasts in Id1 knockdown cells. These data suggest that Id1 is crucial for RANKL-induced osteoclastogenesis in RAW264.7 cells and that Id1 is likely a downstream effector of WSS25 that is involved in the inhibition of osteoclast formation.

\section{Discussion}

Bone is constantly updated, and under normal physiological conditions, maintains homeostasis through the formation of osteoblasts and resorption by osteoclasts. However, redundant RANKL signaling increases the formation and resorption of osteoclasts, leading to pathologic and osteopenic diseases that include postmenopausal osteoporosis, rheumatoid arthritis, lytic bone metastasis, periodontitis, and bone tumors ${ }^{[39]}$. Therefore, the downregulation of RANKL and its downstream signaling effectors may be a valuable approach used to treat osteoclast related diseases ${ }^{[41]}$. WSS25 has been suggested as a tumor angiogenesis inhibiting drug candidate for hepatocellular cancer therapy ${ }^{[26]}$, and it may inhibit angiogenesis in tumors by downregulating Dicer and microRNA-210 ${ }^{[26,28]}$. Surprisingly, we found that WSS25 blocked RANKL-induced osteoclastogenesis, actin ring formation, bone resorption, and osteoclastogenesis-related gene marker expression, including TRAP, NFATc1, cathepsin K, and MMP-9, in vitro. In addition, WSS25 reduced ovariectomy-induced bone loss in vivo. BMP-2 enhanced RAW264.7 cell differentiation in the presence of a suboptimal dose of RANKL, but the induction of osteoclasts by RANKL was largely blocked by WSS25. This was at least partially because the phosphorylation of Smad1/5/8 and Id1 were impaired by WSS25, because RANKL-induced osteoclast differentiation was promoted by Id1 and its signaling pathway. The NF-kB, p38, and JNK signaling pathways were not affected by WSS25, while a modest effect on the ERK signaling pathway was induced by WSS25 (data not shown).

Previous studies showed that BMP-2 and BMP receptors 
A

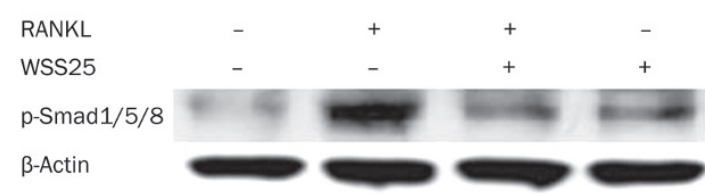

C

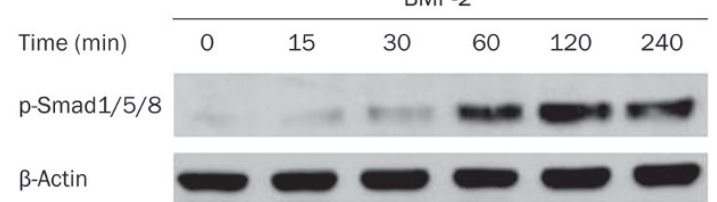

E

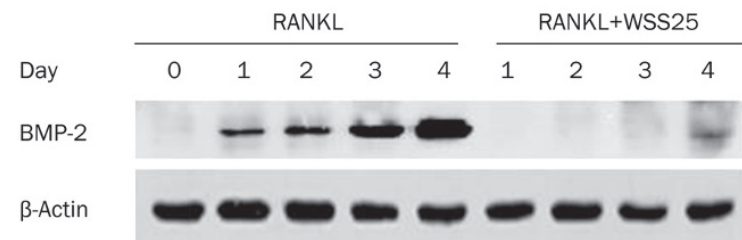

B

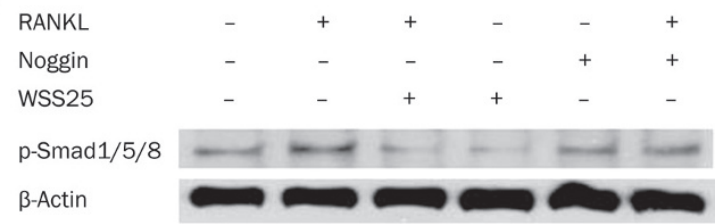

D

BMP-2

Noggin

WSS25

p-Smad1/5/8

$\beta$-Actin

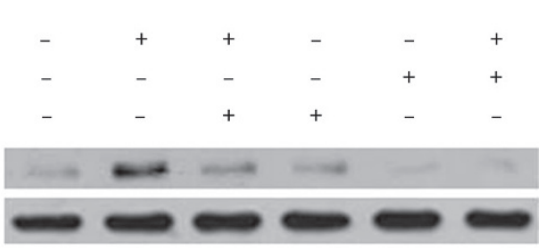

Figure 6. WSS25 inhibits the RANKL- or BMP-2-induced phosphorylation of Smad1/5/8 in RAW264.7 cells. (A, B) RAW264.7 cells ( $1 \times 10^{6}$ cells/mL) were incubated with RANKL $(50 \mathrm{ng} / \mathrm{mL})$ in the presence or absence of WSS25 $(10 \mu \mathrm{g} / \mathrm{mL})$ or noggin $(250 \mathrm{ng} / \mathrm{mL})$ for $22 \mathrm{~h}$. Cells were then lysed. The phosphorylation Smad1/5/8 was detected by Western blot. (C) RAW264.7 cells were incubated with BMP-2 (100 ng/mL) for the indicated times. The cells were lysed and the phosphorylation of Smad1/5/8 was detected by Western blot. (D) RAW264.7 cells were stimulated with BMP-2 (100 ng/mL) and treated with WSS25 $(10 \mu \mathrm{g} / \mathrm{mL})$ or noggin $(250 \mathrm{ng} / \mathrm{mL})$ for $60 \mathrm{~min}$. Then, the cells were lysed and the extracts were probed with anti-pSmad1/5/8 antibody. (E) RAW264.7 cells were incubated with RANKL (50 ng/mL), in the presence or absence of WSS25 (10 $\mu \mathrm{g} / \mathrm{mL})$, on the indicated days. BMP-2 expression was detected by immunoblotting.

A

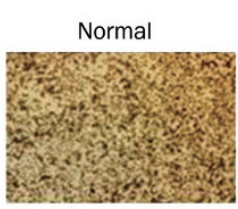

RANKL+BMP-2

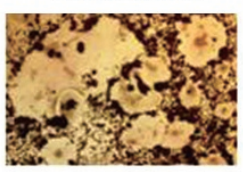

D

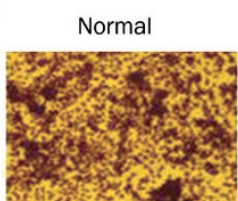

BMP-2

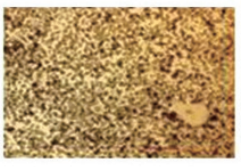

RANKL+BMP-2 + Noggin

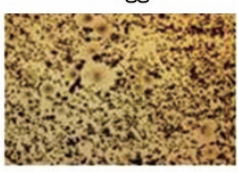

RANKL

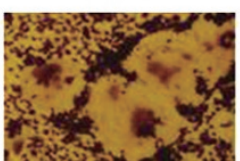

RANKL

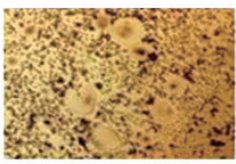

RANKL+BMP-2 +WSS25

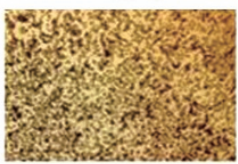

RANKL+Noggin

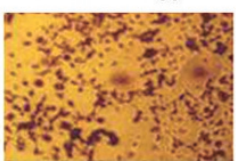

B
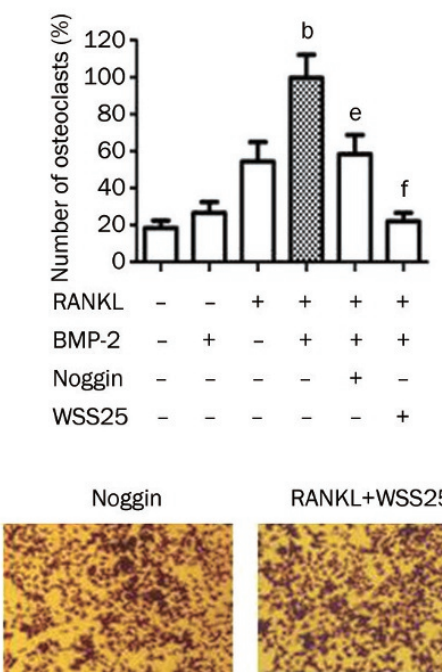

c

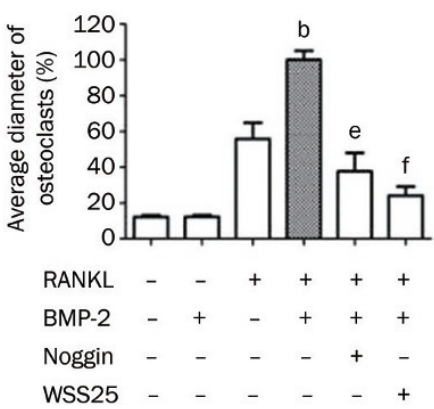

Figure 7. BMP-2 enhances RANKL-induced osteoclast formation. However, WSS25 blocks this induction in RAW264.7 cells. (A) RAW264.7 cells $\left(1 \times 10^{5}\right.$ cells $/ \mathrm{mL})$ were incubated with BMP-2 $(100 \mathrm{ng} / \mathrm{mL})$, RANKL $(20 \mathrm{ng} / \mathrm{mL})$, or both, in the presence or absence of WSS25 $(10 \mu \mathrm{g} / \mathrm{mL})$ or noggin $(1 \mu \mathrm{g} / \mathrm{mL})$ for $4 \mathrm{~d}$. Cells were then stained for TRAP expression detection and photographed $(\times 1000)$. (B) The numbers of TRAP-positive, multinucleated $(\geq 3$ nuclei) osteoclasts were counted. (C) The average diameter of multinucleated osteoclasts was calculated. (D) RAW264.7 cells $\left(1 \times 10^{5} \mathrm{cells} / \mathrm{mL}\right)$ were incubated with RANKL $(50 \mathrm{ng} / \mathrm{mL})$ and treated with noggin $(1 \mu \mathrm{g} / \mathrm{mL})$ or WSS25 $(10 \mu \mathrm{g} / \mathrm{mL})$. After $4 \mathrm{~d}$, multinucleated osteoclasts were stained with TRAP solution. $n=3$. Values are shown as the mean \pm SD. ${ }^{b} P<0.05$ vs RANKL group. ${ }^{e} P<0.05,{ }^{f} P<0.01$ vs RANKL+BMP- 2 group.

induced osteoclast differentiation in vitro ${ }^{[15,42,43]}$. A BMP-2 antagonist, noggin, impaired the RANKL-induced differentiation of osteoclast-like cells in RAW264.7 cells $^{[42]}$. Overexpressing noggin in mice attenuated BMP activity, increasing bone volume and decreasing the number of osteoclasts. This effect was rescued by recombinant BMP- $2^{[44]}$. It was also reported that BMPR-IA and BMPR-IB might negatively regulate the differentiation of osteoclasts, and BMPR-II is expressed in the 
A

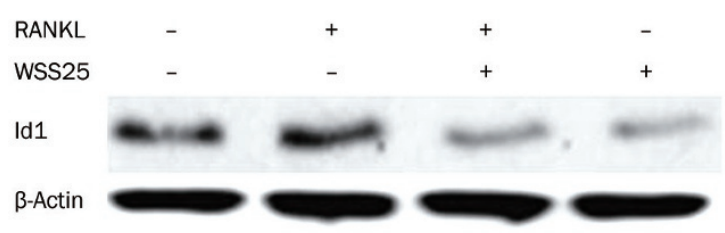

C

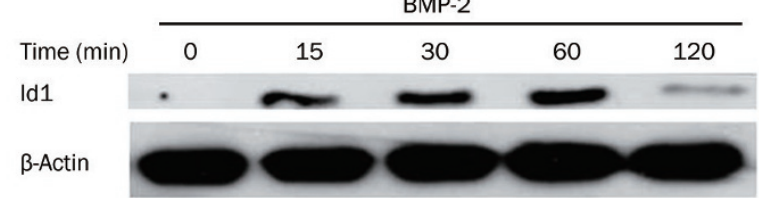

E
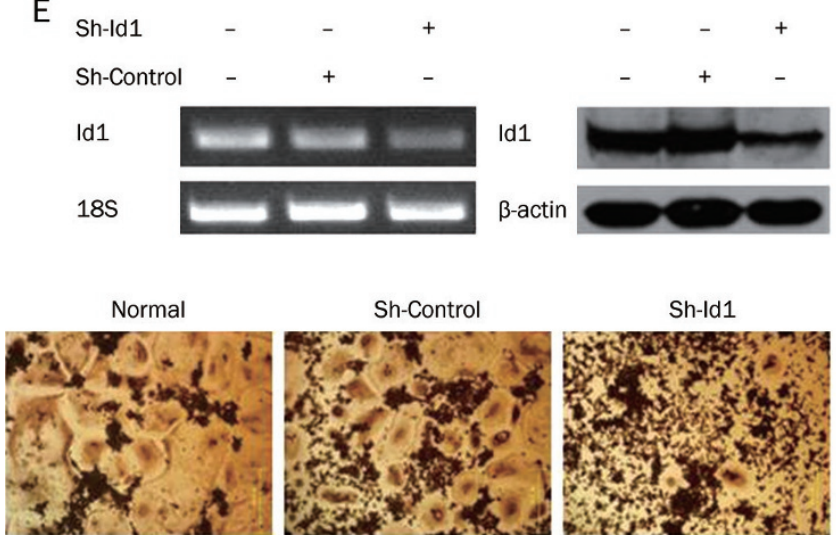

B

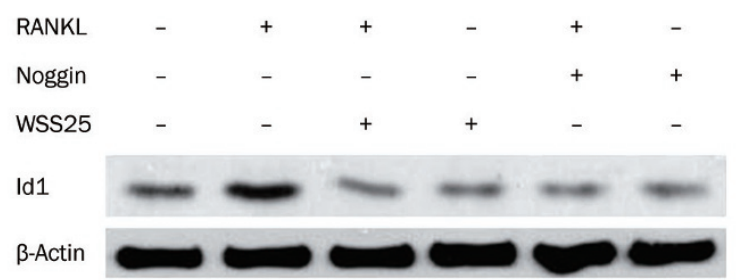

D

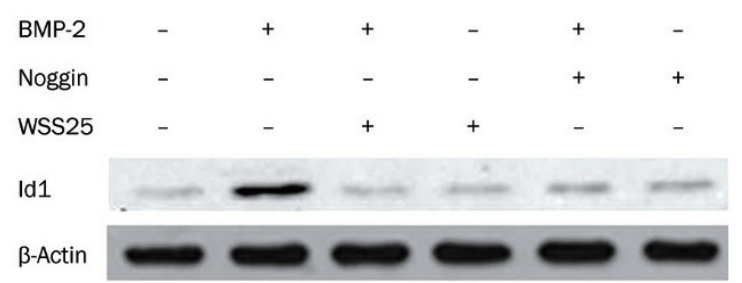

$\mathrm{F}$
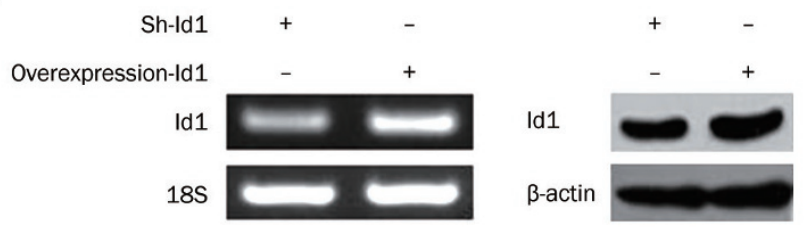

Sh-Id1+

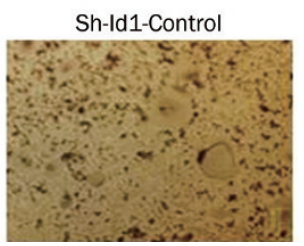
Overexpression-Id1

Figure 8. WSS25 inhibits the RANKL-induced expression of Id 1 in RAW264.7 cells. (A) RAW264.7 cells ( $1 \times 10^{6}$ cells $\left./ \mathrm{mL}\right)$ were treated with RANKL ( 50 $\mathrm{ng} / \mathrm{mL}$ ), in the presence or absence of WSS25 $(10 \mu \mathrm{g} / \mathrm{mL})$, for $22 \mathrm{~h}$. The expression of Id 1 was detected by Western blot assay. (B) RAW264.7 cells ( $1 \times 10^{6}$ cells $/ \mathrm{mL}$ ) were incubated with RANKL ( $50 \mathrm{ng} / \mathrm{mL})$, in presence or absence of WSS25 (10 $\mu \mathrm{g} / \mathrm{mL})$ and noggin $(250 \mathrm{ng} / \mathrm{mL})$, for $22 \mathrm{~h}$. The expression of Id 1 was detected by immunoblotting. (C) The cells were treated with BMP-2 for the indicated times and the expression of Id 1 was measured by Western blot assay. (D) RAW264.7 cells were treated with BMP-2 $(100 \mathrm{ng} / \mathrm{mL})$, in the presence or absence of WSS25 $(10 \mu \mathrm{g} / \mathrm{mL}) \mathrm{or}$ noggin $(250 \mathrm{ng} / \mathrm{mL})$, for $60 \mathrm{~min}$. Then, the cells were lysed and the extracts were probed with anti-Id1 antibody. (E) The expression of Id1 was detected by reverse transcription PCR and Western blot analysis. RAW264.7 cells, negative control cells, and Id 1 gene knockdown RAW264.7 cells $\left(1 \times 10^{5} \mathrm{cells} / \mathrm{mL}\right)$ were treated with RANKL ( $50 \mathrm{ng} / \mathrm{mL}$ ) for $4 \mathrm{~d}$. Cells were then stained by TRAP and photographed. (F) The expression of Id1 was detected by reverse transcription PCR and Western blot analysis. In a final set of cells, Id 1 was first genetically knocked down in RAW264.7 cells, and then overexpressed $\left(1 \times 10^{5}\right.$ cells $\left./ \mathrm{mL}\right)$. These cells were treated with RANKL $(50 \mathrm{ng} / \mathrm{mL})$ for $4 \mathrm{~d}$ before they were stained with TRAP and photographs were taken $(\times 100)$.

multinucleated osteoclasts that are involved in bone remodeling $^{[44,45]}$. In this study, we found that the expression of BMP-2 was gradually increased in RANKL-induced RAW264.7 cells, but that WSS25 blocked this effect. Moreover, the expression of the BMP receptors BMP-IB and BMP-II were increased by RANKL in a time dependent manner, but WSS25 had no significant effect on this increase (data not shown). These results suggest that WSS25 impairs the RANKL-induced differentiation of osteoclasts in RAW264.7 cells by suppressing BMP-2 signaling.

Furthermore, we demonstrated that WSS25 inhibited the phosphorylation of Smad1/5/8 in RAW264.7 cells. Id1 and Id3, downstream effectors of Smad1/5/8, have partially overlapping functions and can compensate for each other ${ }^{[46]}$. Interestingly, WSS25 significantly inhibited RANKL-induced Id1 expression but had little effect on RANKL-induced Id3 expression in RAW264.7 cells (data not shown). Generally, Id proteins have dual functions whereby they inhibit cell differentiation and stimulate cell proliferation. We found that Id1 gene knockdown suppressed RANKL-induced osteoclastogenesis in RAW264.7 cells. Furthermore, overexpression of Id1 partially rescued Id1 silencing by shRNA in RAW264.7 cells. The above data suggest that WSS25 inhibits RANKL-induced osteoclast differentiation by impairing the function of Id1, but not Id3. These results suggest that WSS25 impairs the differentiation of osteoclasts by downregulating BMP-2 signaling.

Moreover, as a type of macromolecule, polysaccharides are suspected of oral absorption. It has been reported that $\beta-1-$ 3-glucan is absorbed by intestinal epithelial cells after oral administration $^{[47,48]}$. In addition, in a Caco-2 cell absorption model, we found that the apparent permeability coefficient $\left(P_{\text {app }}\right)$ value of WSS25 was higher than $1 \times 10^{-6} \mathrm{~cm} / \mathrm{s}$, which 
indicated that WSS25 could be absorbed in this in vitro model (unpublished data). Many types of polysaccharides (eg, 1,3-linked glucan, 1,4-linked glucan, 1,6-linked polysaccharide and sulfated polysaccharide) are absorbed by intestinal epithelial cells and enter the circulation after oral administration, even when they have a large molecular weight, and most of them persist in their original form in plasma while the rest undergo degradation, to varying degrees (unpublished data).

In summary, we demonstrated that WSS25 inhibited osteoclast formation in vitro and reduced OVX-induced bone loss in vivo. Moreover, this inhibition may be mediated by blocking the RANKL-induced BMP2/Smad1/5/8 signaling pathway and Id1 function. Taken together, WSS25 is a potential agent for use in the treatment of osteoporosis.

\section{Acknowledgements}

This work was supported by grants from the National Natural Science Foundation of China (NSFC) (No 31230022), the National Science Fund for Distinguished Young Scholars (№ 81125025), and the New Drug Creation and Manufacturing Program (No 2012ZX09301001-003).

\section{Author contribution}

Kan DING and Hai-ying WANG designed research; Cheng CHEN, Yi QIN, Jian-ping FANG, Xin-yan NI and Jian YAO performed research; Cheng CHEN, Yi QIN and Jian-ping FANG analyzed data; Cheng CHEN and Yi QIN wrote the paper.

\section{References}

1 Fujisaki K, Tanabe N, Suzuki N, Kawato T, Takeichi O, Tsuzukibashi O, et al. Receptor activator of NF-kappaB ligand induces the expression of carbonic anhydrase II, cathepsin $\mathrm{K}$, and matrix metalloproteinase-9 in osteoclast precursor RAW264.7 cells. Life Sci 2007; 80: 1311-8.

2 Wada T, Nakashima T, Hiroshi N, Penninger JM. RANKL-RANK signaling in osteoclastogenesis and bone disease. Trends Mol Med 2006; 12: 17-25.

3 Boyle WJ, Simonet WS, Lacey DL. Osteoclast differentiation and activation. Nature 2003; 423: 337-42.

4 Nakashima T, Hayashi M, Fukunaga T, Kurata K, Oh-Hora M, Feng JQ, et al. Evidence for osteocyte regulation of bone homeostasis through RANKL expression. Nat Med 2011; 17: 1231-4.

5 Kikuta J, Ishii M. Osteoclast migration, differentiation and function: novel therapeutic targets for rheumatic diseases. Rheumatology 2013; 52: 226-34.

6 Baud'huin M, Lamoureux F, Duplomb L, Redini F, Heymann D. RANKL, RANK, osteoprotegerin: key partners of osteoimmunology and vascular diseases. Cell Mol Life Sci 2007; 64: 2334-50.

7 Teitelbaum SL. Bone resorption by osteoclasts. Science 2000; 289: 1504-8.

8 Ashley JW, McCoy EM, Clements DA, Shi Z, Chen T, Feng X. Development of cell-based high-throughput assays for the identification of inhibitors of receptor activator of nuclear factor-kappa B signaling. Assay Drug Dev Technol 2011; 9: 40-9.

9 Wittrant Y, Theoleyre S, Couillaud S, Dunstan C, Heymann D, Redini F. Relevance of an in vitro osteoclastogenesis system to study receptor activator of NF-KB ligand and osteoprotegerin biological activities. Exp Cell Res 2004; 293: 292-301.
10 Tsai HY, Lin HY, Fong YC, Wu JB, Chen YF, Tsuzuki M, et al. Paeonol inhibits RANKL-induced osteoclastogenesis by inhibiting ERK, p38 and NF-kappaB pathway. Eur J Pharmacol 2008; 588: 124-33.

11 Takayanagi H, Kim S, Koga T, Nishina H, Isshiki M, Yoshida H, et al. Induction and activation of the transcription factor NFATc1 (NFAT2) integrate RANKL signaling in terminal differentiation of osteoclasts. Dev Cell 2002; 3: 889-901.

12 Teitelbaum SL, Ross FP. Genetic regulation of osteoclast development and function. Nat Rev Genet 2003; 4: 638-49.

13 Okamoto M, Murai J, Yoshikawa H, Tsumaki N. Bone morphogenetic proteins in bone stimulate osteoclasts and osteoblasts during bone development. J Bone Miner Res 2006; 21: 1022-33.

14 Pham L, Beyer K, Jensen ED, Rodriguez JS, Davydova J, Yamamoto $\mathrm{M}$, et al. Bone morphogenetic protein 2 signaling in osteoclasts is negatively regulated by the BMP antagonist, twisted gastrulation. J Cell Biochem 2011; 112: 793-803.

15 Itoh K, Udagawa N, Katagiri T, lemura S, Ueno N, Yasuda H, et al. Bone morphogenetic protein 2 stimulates osteoclast differentiation and survival supported by receptor activator of nuclear factor-kappaB ligand. Endocrinology 2001; 142: 3656-62.

16 Lee J, Kim K, Kim JH, Jin HM, Choi HK, Lee SH, et al. Id helix-loophelix proteins negatively regulate TRANCE-mediated osteoclast differentiation. Blood 2006; 107: 2686-93.

17 Yokota Y, Mori S. Role of Id family proteins in growth control. J Cell Physiol 2002; 190: 21-8.

18 Chan AS, Jensen KK, Skokos D, Doty S, Lederman HK, Kaplan RN, et al. Id1 represses osteoclast-dependent transcription and affects bone formation and hematopoiesis. PloS One 2009; 4: e7955.

19 Abe E. Function of BMPs and BMP antagonists in adult bone. Ann N Y Acad Sci 2006; 1068: 41-53.

20 Sotillo Rodriguez JE, Mansky KC, Jensen ED, Carlson AE, Schwarz T, Pham L, et al. Enhanced osteoclastogenesis causes osteopenia in twisted gastrulation-deficient mice through increased BMP signaling. J Bone Miner Res 2009; 24: 1917-26.

21 Watts NB, Diab DL. Long-term use of bisphosphonates in osteoporosis. J Clin Endocr Metab 2010; 95: 1555-65.

22 Kennel KA, Drake MT. Adverse effects of bisphosphonates: implications for osteoporosis management. Mayo Clin Proc 2009; 84: 632-8.

23 Miyakoshi N. Effects of parathyroid hormone on cancellous bone mass and structure in osteoporosis. Curr Pharm Design 2004; 10: 2615-27.

24 Pearce $\mathrm{CL}$, Chung K, Pike MC, Wu AH. Increased ovarian cancer risk associated with menopausal estrogen therapy is reduced by adding a progestin. Cancer 2009; 115: 531-9.

25 Qiu H, Tang W, Tong XK, Ding K, Zuo JP. Structure elucidation and sulfated derivatives preparation of two alpha- $D$-glucans from Gastrodia elata BI. and their anti-dengue virus bioactivities. Carbohyd Res 2007; 342: 2230-6.

26 Qiu H, Yang B, Pei ZC, Zhang Z, Ding K. WSS25 inhibits growth of xenografted hepatocellular cancer cells in nude mice by disrupting angiogenesis via blocking bone morphogenetic protein (BMP)/Smad/ Id1 signaling. J Biol Chem 2010; 285: 32638-46.

27 Chen X, Xiao F, Wang Y, Fang JP, Ding K. Structure-activity relationship study of WSS25 derivatives with anti-angiogenesis effects. Glycoconj J 2012; 29: 389-98.

28 Xiao F, Qiu H, Zhou L, Shen X, Yang L, Ding K. WSS25 inhibits Dicer, downregulating microRNA-210, which targets Ephrin-A3, to suppress human microvascular endothelial cell (HMEC-1) tube formation. Glycobiology 2013; 23: 524-35.

29 Ariyoshi W, Takahashi T, Kanno T, Ichimiya H, Shinmyouzu K, Takano H, 
et al. Heparin inhibits osteoclastic differentiation and function. J Cell Biochem 2008; 103: 1707-17.

30 Wei ZF, Tong B, Xia YF, Lu Q, Chou GX, Wang ZT, et al. Norisoboldine suppresses osteoclast differentiation through preventing the accumulation of TRAF6-TAK1 complexes and activation of MAPKs/NFkappa B/c-Fos/NFATc1 pathways. PloS One 2013; 8 (3). e59171. doi: 10.1371/journal.pone.0059171.

31 Mori-Okamoto J, Otawara-Hamamoto $\mathrm{Y}$, Yamato H, Yoshimura $\mathrm{H}$. Pomegranate extract improves a depressive state and bone properties in menopausal syndrome model ovariectomized mice. J Ethnopharmacol 2004; 92: 93-101.

32 Wilson SR, Peters C, Saftig P, Bromme D, Cathepsin K. Activitydependent regulation of osteoclast actin ring formation and bone resorption. J Biol Chem 2009; 284: 2584-92.

33 Negishi-Koga T, Takayanagi H. $\mathrm{Ca}^{2+}$-NFATc1 signaling is an essential axis of osteoclast differentiation. Immunol Rev 2009; 231: 241-56.

34 Roggia C, Gao YH, Cenci S, Weitzmann MN, Toraldo G, Isaia G, et al. Up-regulation of TNF-producing T cells in the bone marrow: A key mechanism by which estrogen deficiency induces bone loss in vivo. Proc Natl Acad Sci U S A 2001; 98: 13960-5.

35 Sun L, Vukicevic S, Baliram R, Yang G, Sendak R, McPherson J, et al. Intermittent recombinant TSH injections prevent ovariectomy-induced bone loss. Proc Natl Acad Sci U S A 2008; 105: 4289-94.

36 Xu J, Li ZX, Luo J, Yang F, Liu T, Liu MY, et al. Synthesis and biological evaluation of heterocyclic ring-fused betulinic acid derivatives as novel inhibitors of osteoclast differentiation and bone resorption. J Med Chem 2012; 55: 3122-34.

37 Marie PJ. Strontium ranelate: a novel mode of action optimizing bone formation and resorption. Osteoporos Int 2005; 16 Suppl 1: S7-10.

38 Edwards MW, Bain SD, Bailey MC, Lantry MM, Howard GA. 17 beta estradiol stimulation of endosteal bone formation in the ovariectomized mouse: an animal model for the evaluation of bone-targeted estrogens. Bone 1992; 13: 29-34.
39 Chen G, Deng C, Li YP. TGF-beta and BMP signaling in osteoblast differentiation and bone formation. Int J Biol Sci 2012; 8: 272-88.

40 Theill LE, Boyle WJ, Penninger JM. RANK-L and RANK: T cells, bone loss, and mammalian evolution. Annu Rev Immunol 2002; 20: 795823.

41 Lee JH, Jin H, Shim HE, Kim HN, Ha H, Lee ZH. Epigallocatechin3-gallate inhibits osteoclastogenesis by down-regulating c-Fos expression and suppressing the nuclear factor-kappaB signal. Mol Pharmacol 2010; 77: 17-25.

42 Jensen ED, Pham L, Billington CJ Jr, Espe K, Carlson AE, Westendorf $\mathrm{JJ}$, et al. Bone morphogenic protein 2 directly enhances differentiation of murine osteoclast precursors. J Cell Biochem 2010; 109: 672-82.

43 Paul S, Lee JC, Yeh LC. A comparative study on BMP-induced osteoclastogenesis and osteoblastogenesis in primary cultures of adult rat bone marrow cells. Growth Factors 2009; 27: 121-31.

44 Okamoto M, Murai J, Imai Y, Ikegami D, Kamiya N, Kato S, et al. Conditional deletion of Bmpr1a in differentiated osteoclasts increases osteoblastic bone formation, increasing volume of remodeling bone in mice. J Bone Miner Res 2011; 26: 2511-22.

45 Onishi T, Ishidou Y, Nagamine T, Yone K, Imamura T, Kato M, et al. Distinct and overlapping patterns of Iocalization of bone morphogenetic protein (BMP) family members and a BMP type II receptor during fracture healing in rats. Bone 1998; 22: 605-12.

46 Miyazono K, Miyazawa K. Id: a target of BMP signaling. Sci STKE 2002; 2002: pe40.

47 Rice PJ, Adams EL, Ozment-Skelton T, Gonzalez AJ, Goldman MP, Lockhart BE, et al. Oral delivery and gastrointestinal absorption of soluble glucans stimulate increased resistance to infectious challenge. J Pharmacol Exp Ther 2005; 314: 1079-86.

48 Tomita M, Miwa M, Ouchi S, Oda T, Aketagawa J, Goto Y, et al. Nonlinear intestinal absorption of (1-->3)-beta-D-glucan caused by absorptive and secretory transporting system. Biol Pharm Bull 2009; 32: 1295-7. 